\title{
IMPACT OF FEEDING SOME FORAGE SHRUBS ON MILK, BLOOD PARAMETERS OF EWES AND GROWTH PERFORMANCE OF THEIR OFFSPRINGS IN NORTHERN COAST.
}

\author{
EL-Saadany, S.A.*; E.S.H. EL-Gohary**; H.H. Omar***; EL.A. EL-wakeel*and
}

I.A. EL-sayed*

* Animal Nutrition Research Department,

** Sheep and Goats Research Department,

***Dairy Technology Research Department, Animal Production Research Institute, Agricultural Research Center, Ministry of Agriculture, Egypt.

\begin{abstract}
Forty mature Barki ewes at late pregnancy , 3-4 years old and $45.2 \pm 0.47 \mathrm{~kg}$ live body weight (LBW) divided into equal four groups were used in this work. This experiment aimed to evaluate the effect of feeding Acacia (AC) Acacia saligna , Atriplex (AT) Atriplex halimus, Cassava (CA) Manihot esculenta. compared to berseem (Trifolium Alexandrinum) hay (BH) on yield, chemical composition and rheological properties of milk, hematological and biochemical blood parameters of ewes, and growth performance of their offspring's. Ewes were fed control diet in G1 consisted of : concentrate feed mixture, rice straw plus $\mathrm{BH}$ at levels of 60:10:30\%, respectively. Only BH in (G1) was replaced by AC in (G2), or AT in (G3) or CA in (G4) stems and leaves planted in the salt soil. All animals were kept under the same managerial conditions.

Results showed insignificant effect of dietary treatment on LBW of ewes. Ewes fed AT in (G3) showed higher $(\mathrm{P}<0.05)$ milk yields than in control group $(\mathrm{G} 2)$, while ewes fed CA $(\mathrm{G} 4)$ showed the highest $(\mathrm{P}<0.05)$ milk yields, ewes fed AT $(\mathrm{G} 3)$ did not differ than those in control group (G1). Milk fat, lactose and ash contents in milk were not affected by dietary treatment during all lactation weeks. Protein content was higher $(\mathrm{P}<0.05)$ in $\mathrm{G} 2$ and G3 than in G1 and G4 at all lactation weeks. Total solids (TS) content was lower $(\mathrm{P}<0.05)$ in $\mathrm{G} 4$ than in other groups during the $1^{\text {st }}$ six weeks of lactation, being the highest $(\mathrm{P}>0.05)$ in $\mathrm{G} 1$ at the $7^{\text {th }}$ lactation week. Atriplex treatment was accompanied by high level of ca and $\mathrm{p}$.Calcium and phosphorus content were affected significantly $(\mathrm{P}<0.05)$ by dietary treatment, being significantly $(\mathrm{P}<0.05)$ higher in milk of ewes of $\mathrm{G} 3$ than in G1, G2 and G4 at all lactation weeks. The differences were significantly $(\mathrm{P}<0.05)$ between G2 and (G1 and G4) at all lactation weeks, although no significant different of Calcium content between G1 and G4 except in $6^{\text {th }}$ an $7^{\text {th }}$ week, however, no significant differences of phosphorus content between G2 and G4 although there were no significant differ-ences between them and G1 at all lactation weeks.

Slight differences were detected in acidity, $\mathrm{pH}$ value, density and freezing point of milk, ranging from 0.16 to $-0.20 \%$, $6.62-6.81,30.47-36.27 \%$ and from -0.49 to $-0.64 \%$, respectively. Rennet coagulation time (RCT) values were the lowest through 6 lactation weeks in G2 (98-125 s), and the highest in G4 (143-154 s). Curd tension (CT) was the highest in G2, and the lowest in G4 at 2 and 7 lactation weeks.

Trend of Whey Syneresis values of all treatments was opposite to that of Curd Tension. The highest values was recorded with Cassava.

Red blood cells (RBCs) count did not differ in G2, G3 and G4 than that of G1. White blood cells WBC's count, Ht, \% and $\mathrm{Hg}, \mathrm{g} / \mathrm{dl}$ concentration were higher $(\mathrm{P}<0.05)$ in $\mathrm{G} 4$ than in $\mathrm{G} 2$ and G3. Concentration of total protein $(\mathrm{TP})$, urea-N, Ca and $\mathrm{Ca} / \mathrm{P}$ ratio increased $(\mathrm{P}<0.05)$ in $\mathrm{G} 2$ compared with $\mathrm{G} 4$, while both groups did not differ from those in $\mathrm{G} 1$ and $\mathrm{G} 3$. Concentration of creatinine, triglyceride (TG) and Total cholesterol $(\mathrm{TCh})$ increased $(\mathrm{P}<0.05)$ in $\mathrm{G} 2$ and glucose increased $(\mathrm{P}<0.05)$ in $\mathrm{G} 3$ compared with G1. The effect of dietary treatment on concentration of albumin (AL), globulin (GL), AL/GL ratio and phosphorus $(\mathrm{P})$ in plasma was not significant. Average LBW of lambs at birth was higher $(\mathrm{P}<0.05)$ in G2, G3 and G4 than in G1. The same trend was observed in LBW of males rather than that of females. LBW, total gain and average daily gain of lambs (males and females) was not affected at different ages. Cassava yielded the highest milk production without any adverse effects on live body weight of ewes or their lambs.
\end{abstract}

Keywords: Sheep, halophyte plants, milk, body weight, blood.

\section{INTRODUCTION}

Use of halophytic plants for forage production in salt affected soil was suggested and has been called saline agriculture. In Egypt, about $96 \%$ of the land is desert, where the soil is sandy and most of the available ground-water is too saline to raise and sustain conventional crops. Field trails carried in sandy soil at the sea-coast of Suez Gulf to evaluate the productivity of some local and exotic halophytic plants irrigated with diluted seawater 12.5-50.0\%, (Abou El Nasr et. al., 1996). There is a range of plants that are capable of growing under conditions of saline soil and water. Many of these plants represent a feed resource for livestock. The future prosperity of feed resources in the countries located in the aired and semi-aired regions rely on the economic feasible use of marginal and long-neglected resources. Halophytic plants are one of such resources. These halophytic plants such as Atriplex spp. and Acacia saligna could be used as animal feed components during drought (Gihad and El- Shaer, 1994).

Several attempts have been made to improve the palatability of less and un-palatable halophytic plants through appropriate processing methods. Ensiling halophytic plants with other salt-tolerant plants appeared to be the most convenient processing method, to reduce dependence on limited fresh water forage resources under the prevailing conditions of aridity in Egypt and consequently increase forage availability required for animal production (Abou El Nasr et al., 1996). 
Feeding halophytes is a feasible solution to minimize the expected problems of feed shortage in arid and semi-arid aeries (Safinaz Shawket, et al., 2010). The suitable halophytic forage species that show better adaptability and chances of establishment are Atriplex and Acacia species (Le Houerou, 1992; Degan et al., 1995 and 1997), but high salt content is the major negative component in Atriplex species (Wilson, 1992). Also, Mona Mohammady, et al., (2014) concluded that, it is desirable to allow sheep grazing more than one kind of halophytic forages i.e. Atriplex halimus (saltbush) and Acacia saligna (leguminous tree shrubs) under arid and semi-arid conditions. They found that type of feed had no significant effect on live body weight and average daily gain of lambs of Barki ewes fed berseem hay or halophytic silage without severe biological disorders. Moreover, Abou El Nasr et al., (1996) found that Acacia saligna and Atriplex nummularia (saltbush) offered to adult male sheep in three forms: fresh, processed by air-drying or ensiling, saltbush intake meet energy and protein requirements for maintenance of sheep. Furthermore, Phanthavong and Metha (2004) found that feeding increasing levels of cassava hay and dried cassava root increased milk yield and decreased feed conversion ratio and feed cost. Concentration of ruminal NH3-N and blood urea-N were not affected by level of cassava hay in the diet.

Milk is an important source of all basic nutrients for mammals such as cow, buffalo, goat, sheep and camel is used for different nutritional purposes, including preparation of some nutritional products such as milk cream, butter, yogurt, ghee, sour milk cheese. Yield and composition of milk are influenced by a large number of factors. The most important factors are breed, nutrition, health of animal, environmental and stage of lactation (Rincon, et al., 1994; Park, 2006; Park et al., 2007). Sheep milk is an excellent raw material for the milk processing industry especially in cheese production (Park et al., 2007). Sheep milk contains higher total solid, fat, protein and ash than other milk from cow, goat and human (Rincon et al., 1994; Park et al., 2007). The high fat content $(5.5-8.5 \%)$ in sheep milk gives a higher yield in cheese production compared to cow and provided sufficient digested nutrient (TDN and DCP) to

goat milk, which has a positive impact on the industry and the producer, who may charge a differentiated price for this milk (Ochoa-Cordero et al., 2002 ).

Use of halophytic plants as forges for lactating sheep, goat, cow vary with system of feeding, thus, the objective of the present study was to evaluate the effect of feeding some halophyte plants grown in the North Egyptian deserts, namely, Acacia, Atriplex, Cassava as compared to berseem hay on yield, chemical composition and rheological properties of milk, hematological and biochemical blood parameters of ewes and growth performance of their offspring.

\section{MATERIALS AND METHODS}

This study was carried out at Borg El-Arab Experimental station, belonging to the Animal Production Research Institute, Agricultural Research Center, Ministry of Agriculture.

Animals:

At the beginning of the experimental (January), Forty mature healthy Barki ewes at late pregnancy, aging 3-4 years with average live body weight of $45.2 \pm 0.47 \mathrm{~kg}$ were divided into four similar groups, 10 in each, according to their live body weight (LBW) and age. All animals were kept in a semi-open shaded yard and kept under the same managerial conditions during the experimental period.

Experimental feeding:

Ewes in the $1^{\text {st }}$ group were fed the control diet consisted of concentrate feed mixture (CFM), rice straw (RS) plus berseem hay (BH) at levels of 60:10:30\%, respectively (G1). Only $\mathrm{BH}$ was replaced by leaves and stems of the Acacia (G2), Atriplex (G3) and Cassava (G4) Planted in the salt soil which in diet of the $2^{\text {nd }}, 3^{\text {rd }}$ and $4^{\text {th }}$ groups, respectively, at the same level (30\%).

Animals were fed according to NRC (1985) allowances which were adjusted according to the physiological and productive stage. All animals were fed daily at 9 a.m. and 4 p.m. Fresh water and block minerals were available all times. Chemical composition of feedstuffs were analyzed according to A.O.A.C. (1995) as shown in Table (1).

Table (1): Chemical composition (on dry matter basis) of certain plant species and concentrate feed mixture used in the experimental diets.

\begin{tabular}{|l|c|c|c|c|c|c|c|}
\hline \multirow{2}{*}{ Feed stuff } & \multirow{2}{*}{ DM (\%) } & \multicolumn{7}{|c|}{ Chemical analysis (on DM basis, \%) } \\
\cline { 3 - 8 } & & $\mathbf{O M}$ & $\mathbf{C P}$ & $\mathbf{C F}$ & Fat & NFE & Ash \\
\hline Hay & 95.12 & 89.59 & 10.64 & 38.54 & 1.03 & 39.38 & 10.41 \\
\hline Atriplex & 55.44 & 75.17 & 10.07 & 22.93 & 1.98 & 40.19 & 24.83 \\
\hline Acacia & 52.45 & 91.66 & 15.66 & 31.59 & 1.47 & 42.94 & 8.34 \\
\hline Cassava & 44.39 & 85.26 & 22.94 & 25.05 & 2.92 & 34.35 & 11.74 \\
\hline Rice Straw & 95.0 & 83.18 & 4.91 & 42.04 & 1.97 & 34.26 & 16.82 \\
\hline Concentrate feed mixture & 91.8 & 92.03 & 13.18 & 11.96 & 3.82 & 63.07 & 7.97 \\
\hline
\end{tabular}

\section{Experimental procedures:}

Experiment period were consisted of 2 intervals, late pregnant (30 day pre- partum), and suckling (60 day post-partum). Live body weight of and their offspring's were recorded biweekly.

\section{Milk yield:}

During suckling period, milk yield was recorded after born lambs were allowed to suckle colostrum and milk of their dams for one week. Milk yield was weekly 
recorded for 8 lactation weeks using milk suckling technique. Lambs were isolated from their mothers during previous night and body weight was recorded at the morning. Lambs were left to suckle their dams for 30 minutes, and then body weight was recorded again. The residual milk was hand milked and recorded. Similar procedure was repeating at the evening suckling. The differences in lamb weight before and after suckling for the two suckling's were added to calculate the daily intake of suckling lambs. Milk intake plus milk removed by hand milking represented daily milk yield. All lambs were weaned at 8 wk of age.

Chemical analysis and physical characteristics of milk:

Approximately $100 \mathrm{ml}$ milk of each animal was sampled every week for the determination of milk composition. Individual milk samples were taken from all animals in each group, representing morning and evening milking which were collected weekly from the $2^{\text {nd }}$ up to $7^{\text {th }}$ wk of the suckling period.

Milk samples were directly analyzed for fat, total solids (TS), total proteins, and titratable acidity using the methods described by Ling (1963). Lactose content was determined by the method of calorimetrically according to Barnett and Abd El-Tawab (1957). Cations $\left(\mathrm{Ca}^{+}\right)$was determined according to Page (1982) and Phosphorus according to John (1970). Ash content was determined according the methods reported in A.O.A.C. (1984). Milk PH values were measured using a glass electrode PH meter, (Digital, Model 3305, Jenway). Density and frozen point, as a percent, and somatic cell count (Thousand/ml) were determined using Milko Scan (Mark $^{\circledR}, 133 B$, N. FOSS, Electric, Den mark).

Rheological properties of curd milk:

Rennet coagulation time (RCT) was measured according to method described by (Berrige, 1952). The curd tension (CT) was estimated as described by Chandrosekhara et al., (1975) with modified by Abd ElSalam et al., (1991). The rate of whey syneresis of fresh curd milk was measured as the volume of drained whey after 30, 60, $90 \mathrm{~min}$. It was calculated as percent of volume milk according to Lawerence (1959).

Blood samples:
Blood samples were collected during suckling period from the jugular vein of all ewes in each group into clean test tubes with anticoagulant. Blood samples were divided into two portions. In the $1^{\text {st }}$ portion, hematological parameters including count of red (RBCs, $\times 10^{6} / \mathrm{mm}^{3}$ ) and white (WBCs, $\times 10^{3} / \mathrm{mm}^{3}$ ) blood cells, heamatocrit value $(\mathrm{Ht}, \%)$ and hemoglobin $(\mathrm{Hg}, \mathrm{g} / \mathrm{dl})$ concentration in the whole blood were immediately determined after collection. The $2^{\text {nd }}$ portion of blood samples was centrifuged at $3000 \mathrm{~g}$ for 20 minutes to obtain blood plasma. Concentration of total proteins, albumin, creatinine, urea-N, glucose, triglycerides, total cholesterol and minerals ( $\mathrm{Ca}$ and $\mathrm{P}$ ) were estimated in plasma using commercial chemical reagent kits. However, globulin concentration and albumin/globulin ratio $\mathrm{Ca} / \mathrm{P}$ ratio were calculated.

\section{Statistical analysis:}

Data were statistically analyzed according to SAS (1999, version 8.0). The significant differences were set at $\mathrm{P}<0.05$ according to Duncan (1955).

\section{RESULTS AND DISCUSSION}

\section{Change in live body weight (LBW) of ewes:}

Results shown in Table (2) revealed insignificant differences among different experimental groups in LBW of ewes 15 days pre-partum, at lambing and 60 days post-partum. These results may indicate that feeding ewes on Acacia, Atriplex or Cassava as a source of roughage instead of berseem hay in the diet did not affect nutrient requirements of ewes up to 60 days postpartum.

Results also showed sharp reduction in LBW of ewes in each group at lambing as compared to prepartum weights, but this reduction was higher in G1 than in other roughage groups (G2-G4), being $26.7 \%$ vs. $17.0,17.2$ and $16.9 \%$ in G1, G2, G3 and G4, respectively. These differences may be attributed to litter size of ewes in each group. The observed reduction in LBW of ewes in all groups was mainly due to losing placenta and embryonic membranes as well as lamb borns. LBW of ewes in all groups showed again gradual increase throughout the $1^{\text {st }}$ two post-partum months (Table 2).

Table (2): Live body weight (kg) of ewes in the experimental groups during different physiological stages.

\begin{tabular}{|l|c|c|c|c|}
\hline \multirow{2}{*}{ Period } & \multicolumn{4}{|c|}{ Experimental groups (Mean \pm S.E.) } \\
\cline { 2 - 5 } & G1 & G2 & G3 & G4 \\
\hline 15 days pre-partum & $47.50 \pm 1.47$ & $47.10 \pm 2.09$ & $46.50 \pm 1.19$ & $47.40 \pm 1.96$ \\
\hline At lambing & $37.50 \pm 1.47$ & $39.10 \pm 2.09$ & $38.50 \pm 1.19$ & $39.40 \pm 1.96$ \\
\hline 60 days post-partum & $47.50 \pm 1.47$ & $47.10 \pm 2.04$ & $46.50 \pm 1.19$ & $47.40 \pm 1.96$ \\
\hline
\end{tabular}

In accordance with the present results, Atriplex had no significant effect on the final LBW of ewes (Abu-Zanat, and Tabbaa, 2006). Also, Shaker et al., (2014) showed that Shami goats, in Southern Sinai of Egypt, fed salt fodder shrubs including Acacia saligna had insignificant effect on live body weight and daily gain as compared to the control. These results demonstrated the potentiality of such salt tolerant plants mixture to fulfill the animal requirements to maintain their body weight. Similarly, Shiroma and Akashi (1976) found that goats fed Leucaena leucocephala fodder for three months, maintained their body weights throughout the experimental period without any deleterious effect. Moreover, Zarkawi et al., (2005) demonstrated that Awassi ewes fed Sesbania aculeate which grown on salty soil and irrigated by saline water had comparable live body weight of ewes for control group. Also, Srivastavam and Sharma (1998) found 
non-significant differences final body weight and average daily gain of Jamunapari male goats fed pelleted diets containing different proportions of sundried Leucaena leucocephala. In camels, Abdel-Wahed (2014) concluded that camels grazing halophytes (e.g. Atriplex feeding) responded to supplementation in a way similar to their clover hay fed mates. However, significant $(\mathrm{P}<0.01)$ decrease in weight gain and feed intake was reported with the increase in level of Atriplex in Teddy goats offered $100 \%$ Atriplex amnicola diets (Riaz et al., 1994). From the foregoing results, Atriplex had a pronounced nutritive value as a fodder component when mixed with other plant species for livestock. The main disadvantages of its using alone as animal feed are high ash and mineral contents and insufficient energy density (Afaf Fayed et al., 2010).

\section{Milk production:}

Milk yield:

Results presented in Fig. (1) and shown in Table (3) showed significant differences in weekly, daily and total milk yield among the experimental groups throughout a lactation period of 8 weeks. Ewes fed at in (G3) showed significantly $(\mathrm{P}<0.05)$ higher milk yields than those in AC. G2 group while those in G4 fed Cassava diet showed significantly $(\mathrm{P}<0.05)$ the highest milk yields. However, ewes fed Atriplex diet (G3) did not differ from that in $\mathrm{G} 1$ fed $\mathrm{BH}$.

Throughout 8 lactation weeks during the suckling period, average weekly milk yield showed the same trend of change, showing gradual increase after lambing reaching its peak at the $3^{\text {rd }}$ wk of lactation in all groups, and then it gradually decreased up to 8 weeks of lactation. Ewes in G4 showed the highest milk yield versus the lowest milk yield in G2 (Fig. 1). In camel, Safinaz Shawket et. al., (2010) recorded two peaks (at the $5^{\text {th }}$ and $7^{\text {th }}$ month of calving) of camels fed Atriplex, and one peak (at the $4^{\text {th }}$ month of calving) for those fed $\mathrm{BH}$.

In cows, Davison et al., (1991) suggested that the maximum milk production is not achieved until animals are in a positive energy balance. According to these results, ewes in all groups had negative energy balance during early postpartum period till 3 weeks after lambing, but the observed group differences in milk yield may be due to variation in nutritional state of ewes. Accordingly, the obtained results may indicate impact of feeding ewes during pre- and post-partum period on diet containing CFM plus Cassava or Atriplex on milk yield during the suckling period. However, ewes fed CFM plus Acacia had adverse effect on milk yield as compared to $\mathrm{BH}$.

In agreement with the present results, Safinaz Shawket et. al., (2010) found that inclusion fresh Atriplex (saltbush) instead of $\mathrm{BH}$ in the diet increased $(\mathrm{P}<0.05)$ the milk production of camel. On the other hand, type of roughages had no effect on milk production of goat (Abdalla et al., 2013).

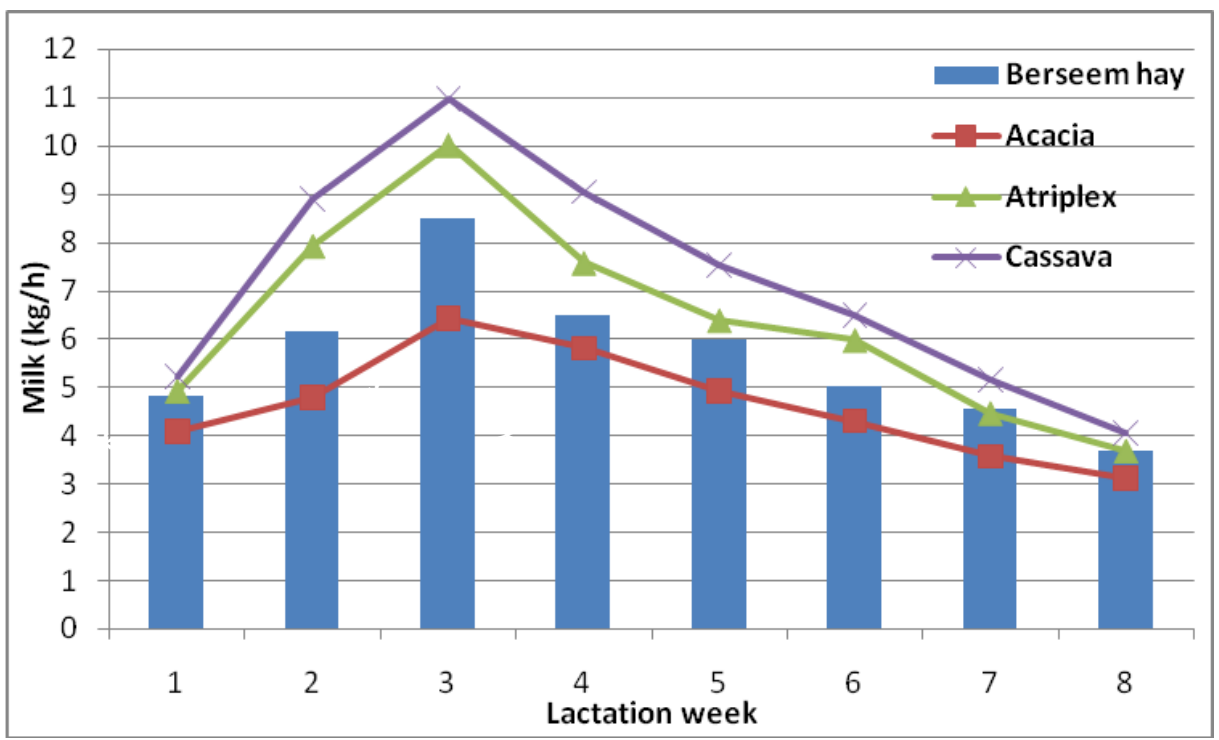

Fig. (1): Changes in weekly milk yield $(\mathrm{kg} / \mathrm{h})$ of ewes in the experimental groups during different weeks of the suckling period. (NS: Not significant. * Significant group differences)

Table (3): Average weekly milk yield $(\mathrm{Kg} / \mathrm{h})$ of ewes in experimental groups during the suckling period.

\begin{tabular}{|l|c|c|c|c|}
\hline \multirow{2}{*}{ Milk yield (kg) } & \multicolumn{3}{|c|}{ Experimental groups (Mean \pm S.E.) } \\
\cline { 2 - 5 } & G1 & G2 & G3 & G4 \\
\hline Average/h $/ \mathrm{wk}$ & $5.69 \pm 0.42^{\mathrm{b}}$ & $4.63 \pm 0.22^{\mathrm{c}}$ & $6.27 \pm 0.39^{\mathrm{b}}$ & $7.17 \pm 0.49^{\mathrm{a}}$ \\
\hline Total/h/8 wk & $45.59 \pm 3.32^{\mathrm{b}}$ & $37.04 \pm 1.77^{\mathrm{c}}$ & $50.19 \pm 3.14^{\mathrm{b}}$ & $57.41 \pm 3.93^{\mathrm{a}}$ \\
\hline
\end{tabular}

a,b and c : Means denoted within the same row with different superscripts are significantly $(\mathbf{P}<0.05)$ different at $P<0.05$.

Also, Abu-Zanat and Tabbaa, (2006) found that milk yield was not affected by feeding ewes on different proportion of saltbush foliage diets (0, 50 and 100\%).
Generally, increasing milk yield of ewes in G4 was mainly attributed to higher dietary $\mathrm{CP}$ and $\mathrm{EE}$ in cassava as compared to other types of forages (Table 1). 


\section{Milk composition:}

Data presented in Table (4) cleared that fat content in milk of ewes was not affected significantly by dietary treatment during all lactation weeks, although there was a tendency of decrease in fat content in milk of ewes fed Cassava as compared to other groups during all lactation weeks. Generally fat content ranged between 6.6 and $7.8 \%$ during lactation weeks, being almost the highest in control ewes fed BH (G1). In all groups, fat content showed gradual increase by advancing lactation week, regardless milk yield (Table
4). In agreement with the present results, Abdalla et al., (2013) found that fat percentages in goat milk were not affected by type of roughages. However, Al-Saiady et al., (2012) reported that dietary energy levels affect only fat and ash percentages in milk. In ewes of G4 fed on Cassava, milk yield significantly $(\mathrm{P}<0.05)$ increased without insignificant decrease in milk fat. Al-Dobaib (2009) reported no changes in milk fat percentage as the milk yield was not increased, which is attributed to the dilution factor. This means that ewes in G4 received their energy requirements for milk production.

Table (4): Changes of milk composition of ewes during suckling period (week) in the experimental groups.

\begin{tabular}{|c|c|c|c|c|c|c|}
\hline \multirow{2}{*}{$\begin{array}{l}\text { Experimental } \\
\text { groups }\end{array}$} & \multicolumn{6}{|c|}{ Suckling period (week) } \\
\hline & 2 & 3 & 4 & 5 & 6 & 7 \\
\hline \multicolumn{7}{|l|}{ Fat $(\%):$} \\
\hline G1 & 7.3 & 7.4 & 7.4 & 7.6 & 7.7 & 7.8 \\
\hline $\mathrm{G} 2$ & 7.1 & 7.2 & 7.4 & 7.5 & 7.6 & 7.7 \\
\hline G3 & 6.8 & 7.1 & 7.1 & 7.2 & 7.4 & 7.5 \\
\hline G4 & 6.6 & 6.8 & 6.9 & 7.0 & 7.2 & 7.4 \\
\hline \pm SEM & 0.549 & 0.24 & 0.804 & 0.557 & 0.580 & 0.630 \\
\hline \multicolumn{7}{|l|}{ Protein $(\%):$} \\
\hline G1 & 4.50 & $4.51^{b}$ & $4.58^{b}$ & $4.71^{b}$ & $4.73^{b}$ & $4.86^{\mathrm{b}}$ \\
\hline $\mathrm{G} 2$ & 4.70 & $4.75^{\mathrm{a}}$ & $4.80^{\mathrm{a}}$ & $4.86^{\mathrm{a}}$ & $4.89^{\mathrm{a}}$ & $5.02^{\mathrm{a}}$ \\
\hline G3 & 4.65 & $4.69^{\mathrm{a}}$ & $4.82^{\mathrm{a}}$ & $4.87^{\mathrm{a}}$ & $4.88^{\mathrm{a}}$ & $4.92^{\mathrm{a}}$ \\
\hline G4 & 4.21 & $4.58^{\mathrm{b}}$ & $4.60^{b}$ & $4.71^{b}$ & $4.77^{b}$ & $4.80^{\mathrm{b}}$ \\
\hline \pm SEM & 0.342 & 0.077 & 0.058 & 0.058 & 0.062 & 0.136 \\
\hline \multicolumn{7}{|l|}{ Lactose (\%): } \\
\hline G1 & 4.60 & 4.63 & 4.68 & 4.76 & 4.81 & 4.90 \\
\hline $\mathrm{G} 2$ & 4.69 & 4.76 & 4.80 & 4.85 & 4.89 & 4.96 \\
\hline G3 & 4.69 & 4.80 & 4.83 & 4.85 & 4.89 & 4.93 \\
\hline G4 & 4.20 & 4.33 & 4.60 & 4.72 & 4.80 & 4.86 \\
\hline \pm SEM & 0.578 & 0.814 & 0.694 & 0.636 & 0.845 & 1.00 \\
\hline \multicolumn{7}{|c|}{ Total solids $(\%)$ : } \\
\hline G1 & $17.67^{\mathrm{a}}$ & $17.93^{\mathrm{a}}$ & $17.18^{\mathrm{a}}$ & $18.57^{\mathrm{a}}$ & $18.66^{\mathrm{a}}$ & 18.95 \\
\hline $\mathrm{G} 2$ & $17.79^{\mathrm{a}}$ & $17.92^{\mathrm{a}}$ & $18.39^{\mathrm{a}}$ & $18.43^{\mathrm{a}}$ & $18.75^{\mathrm{a}}$ & 18.94 \\
\hline G3 & $17.05^{\mathrm{a}}$ & $17.55^{\mathrm{a}}$ & $17.81^{\mathrm{a}}$ & $17.91^{\mathrm{a}}$ & $18.18^{\mathrm{a}}$ & 18.38 \\
\hline G4 & $15.86^{\mathrm{b}}$ & $16.71^{\mathrm{b}}$ & $17.02^{\mathrm{b}}$ & $17.35^{\mathrm{b}}$ & $17.94^{\mathrm{b}}$ & 18.36 \\
\hline \pm SEM & 0.286 & 0.315 & 0.539 & 0.439 & 0.483 & 0.537 \\
\hline \multicolumn{7}{|l|}{ Ash (\%): } \\
\hline G1 & 0.57 & 0.59 & 0.62 & 0.70 & 0.75 & $0.82^{\mathrm{b}}$ \\
\hline $\mathrm{G} 2$ & 0.70 & 0.71 & 0.74 & 0.79 & 0.87 & $0.93^{\mathrm{ab}}$ \\
\hline G3 & 0.71 & 0.73 & 0.75 & 0.80 & 0.88 & $0.96^{\mathrm{a}}$ \\
\hline G4 & 0.65 & 0.67 & 0.69 & 0.73 & 0.80 & $0.90^{\mathrm{ab}}$ \\
\hline \pm SEM & 0.104 & 0.137 & 0.142 & 0.137 & 0.123 & 0.092 \\
\hline \multicolumn{7}{|l|}{ Calcium (g/l): } \\
\hline G1 & $0.47^{\mathrm{C}}$ & $0.44^{\mathrm{c}}$ & $0.40^{\mathrm{c}}$ & $0.38^{\mathrm{c}}$ & $0.37^{\mathrm{d}}$ & $0.35^{\mathrm{d}}$ \\
\hline G2 & $1.51^{\mathrm{b}}$ & $1.64^{\mathrm{b}}$ & $1.73^{\mathrm{b}}$ & $1.75^{\mathrm{b}}$ & $1.88^{\mathrm{b}}$ & $2.01^{\mathrm{b}}$ \\
\hline G3 & $2.57^{\mathrm{a}}$ & $2.60^{\mathrm{a}}$ & $2.64^{\mathrm{a}}$ & $2.73^{\mathrm{a}}$ & $2.77^{\mathrm{a}}$ & $2.82^{\mathrm{a}}$ \\
\hline G4 & $0.54^{\mathrm{c}}$ & $0.59^{\mathrm{c}}$ & $0.64^{c}$ & $0.71^{\mathrm{c}}$ & $0.80^{\mathrm{c}}$ & $0.93^{\mathrm{c}}$ \\
\hline \pm SEM & 0.39 & 0.33 & 0.32 & 0.33 & 0.29 & 0.25 \\
\hline \multicolumn{7}{|c|}{ Phosphorous (g/l): } \\
\hline G1 & $0.30^{\mathrm{c}}$ & $0.33^{\mathrm{d}}$ & $0.35^{\mathrm{c}}$ & $0.38^{\mathrm{c}}$ & $0.39^{\mathrm{c}}$ & $0.42^{\mathrm{c}}$ \\
\hline $\mathrm{G} 2$ & $0.39^{b}$ & $0.46^{\mathrm{b}}$ & $0.57^{\mathrm{b}}$ & $0.66^{\mathrm{b}}$ & $0.78^{\mathrm{b}}$ & $0.83^{\mathrm{b}}$ \\
\hline G3 & $0.78^{\mathrm{a}}$ & $0.81^{\mathrm{a}}$ & $0.86^{\mathrm{a}}$ & $0.91^{\mathrm{a}}$ & $0.94^{\mathrm{a}}$ & $0.99^{\mathrm{a}}$ \\
\hline G4 & $0.45^{\mathrm{b}}$ & $0.54^{\mathrm{b}}$ & $0.63^{b}$ & $0.74^{b}$ & $0.80^{\mathrm{b}}$ & $0.90^{\mathrm{ab}}$ \\
\hline \pm SEM & 0.072 & 0.064 & 0.072 & 0.100 & 0.119 & 0.108 \\
\hline
\end{tabular}

a and b: Means denoted within the same column with different superscripts are significantly $(\mathbf{P}<0.05)$ different at $\mathbf{P}<0.05$.

Protein content was affected significantly $(\mathrm{P}<0.05)$ by dietary treatment, being significantly $(\mathrm{P}<0.05)$ higher in milk of ewes of G2 and G3 than in G1 and G4 at all lactation weeks. The differences were significant at all lactation weeks, except at the $2^{\text {nd }} \mathrm{wk}$.
This trend may be attributed to the negative relationship between protein content and milk yield, which was significantly $(\mathrm{P}<0.05)$ lower in $\mathrm{G} 2$ and $\mathrm{G} 3$ than in $\mathrm{G} 1$. In all groups, protein content showed gradual increase by advancing lactation week, regardless milk yield 
(Table 4). Wilson (1984) reported that dietary protein content will directly affect milk protein content. This finding was true in $\mathrm{G} 2$ because Acacia contained high $\mathrm{CP}$ content.

No marked effect of dietary treatment was observed on the lactose content and the differences among the experimental groups were not significant. Lactose content ranged between 4.20 and $4.96 \%$ in all groups at all lactation weeks (Table 4). It is well known that lactose levels in milk are highly affected by genetic factors and minor by feeding. However, the insignificant effect of the experimental diets on lactose content in ewe milk could be due to similar type of vegetation eaten (Khaskheli et al., 2005).

Total solids (TS) content was significantly $(\mathrm{P}<0.05)$ lower in milk of ewes fed Cassava diet $(\mathrm{G} 4)$ than in other groups (G1-G3) during the $1^{\text {st }}$ six weeks of lactation. At the $7^{\text {th }}$ week of suckling period, TS content was insignificantly the highest in G1 (control treatment).

Regarding the effect of dietary treatment on ash content in milk, no marked changes occurred at all lactation weeks, except at the $7^{\text {th }}$ week, whereas ash content was significantly $(\mathrm{P}<0.05)$ the highest in $\mathrm{G} 3$ and the lowest in G1 (Table 4). The highest ash content in milk of ewes fed Atriplex diet was attributed to the highest ash content in this forage as compared to other types of forages (Table 1). Mervat Mohammed (2008) found wide variation in ash content of Barki sheep milk at mid-lactation, ranging between 0.62 and $0.96 \%$.

Type of feed about halophyte plants has remarkable effect on minerals content. Atriplex treatment was accompanied by high level of ca and p .Calcium and phosphorus content were affected significantly $(\mathrm{P}<0.05)$ by dietary treatment, being significantly $(\mathrm{P}<0.05)$ higher in milk of ewes of G3 than in G1, G2 and G4 at all lactation weeks. The differences were significantly $(\mathrm{P}<0.05)$ between $\mathrm{G} 2$ and $(\mathrm{G} 1$ and $\mathrm{G} 4)$ at all lactation weeks, although no significant different of Calcium content between G1 and G4 except in $6^{\text {th }}$ an $7^{\text {th }}$ week, however, no significant differences of phosphorus content between G2 and G4 although there were no significant differ-ences between them and G1 at all lactation weeks. These results are in line with finding by Hassan, (2009) and Rincor et. al., (1994). In addition, Renner (1982) reported that minerals contents of sheep milk seem to be very much more those of cow milk due to feeding differences and months of the years. These results agreement with Bayoumi, (1990) who show that the halophytes contained higher level of $\mathrm{Na}, \mathrm{K}, \mathrm{Ca}$.

Changes in acidity, pH value, density and frozen point of ewe milk:

Results shown in Table (5) revealed that acidity, $\mathrm{pH}$ value, density and frozen point of ewe milk showed slight differences among the experimental groups. Milk acidity ranged between $0.17-0.19 \%$ for fresh milk at week 2, and decreased gradually to be between 0.16$0.17 \%$ at week 7 . The $\mathrm{PH}$ values of fresh milk ranged between 6.59-6.79 at week 2, reaching 6.61-6.81 by week 7. Density and frozen point showed inconsistent trend of changes among the experimental groups at different lactation weeks. Generally, acidity, $\mathrm{pH}$ value, density and frozen point ranged between $0.16-0.20 \%$, $6.62-6.81,30.47-36.27 \%$ and from -0.49 to $-0.64 \%$, respectively. It is well known that acidity and $\mathrm{pH}$ value of ewe milk was mainly affected by chemical composition of milk.

Reducing TS content in milk of G4 was associated with insignificant decrease in fat content and significant decrease in protein content (Table 4). There was a gradual increase of TS content in milk as time of lactation progressed in all groups. Such results may be related to feed intake of different forages in the experimental groups, which may be due to the high palatability of clover hay as compared with halophytes contained higher level of $\mathrm{Na}, \mathrm{K}, \mathrm{Ca}$ and silica contents (Bayoumi, 1990).

Table (5): Acidity, pH value, density (\%) and freezing point (\%) in ewes milk in the experimental groups during different weeks of the suckling period.

\begin{tabular}{|l|c|c|c|c|c|c|}
\hline \multirow{2}{*}{ Groups } & \multicolumn{7}{|c|}{ Suckling period (week ) } \\
\cline { 2 - 7 } & $\mathbf{2}$ & $\mathbf{3}$ & $\mathbf{4}$ & $\mathbf{5}$ & $\mathbf{6}$ & $\mathbf{7}$ \\
\hline Acidity (\%): & 0.18 & 0.18 & 0.19 & 0.18 & 0.17 & 0.17 \\
\hline G1 & 0.19 & 0.18 & 0.20 & 0.18 & 0.17 & 0.16 \\
\hline G2 & 0.18 & 0.17 & 0.19 & 0.18 & 0.16 & 0.16 \\
\hline G3 & 0.17 & 0.17 & 0.18 & 0.19 & 0.18 & 0.17 \\
\hline G4 & \multicolumn{7}{|c|}{} \\
\hline PH value: & 6.68 & 6.67 & 6.58 & 6.59 & 6.60 & 6.61 \\
\hline G1 & 6.72 & 6.71 & 6.72 & 6.77 & 6.78 & 6.81 \\
\hline G2 & 6.79 & 6.72 & 6.73 & 6.71 & 6.74 & 6.77 \\
\hline G3 & 6.62 & 6.61 & 6.60 & 6.62 & 6.65 & 6.69 \\
\hline G4 & $32.72 \pm 0.67$ & $32.60 \pm 0.53$ & $33.35 \pm 0.59$ & $33.34 \pm 0.34$ & $30.44 \pm 1.78$ & $32.34 \pm 0.93$ \\
\hline Density (\%): & $36.27 \pm 0.72$ & $34.04 \pm 0.94$ & $34.34 \pm 0.63$ & $33.59 \pm 1.19$ & $32.09 \pm 0.73$ & $35.13 \pm 0.60$ \\
\hline G1 & $35.90 \pm 0.75$ & $34.62 \pm 1.01$ & $34.26 \pm 0.32$ & $32.84 \pm 0.57$ & $34.54 \pm 0.39$ & $34.34 \pm 0.51$ \\
\hline G2 & $30.47 \pm 3.43$ & $33.93 \pm 0.70$ & $34.25 \pm 0.55$ & $32.69 \pm 1.26$ & $33.04 \pm 0.67$ & $34.11 \pm 0.74$ \\
\hline G3 & \multicolumn{7}{|l|}{} \\
\hline G4 & $-0.57 \pm 0.03$ & $-0.58 \pm 0.03$ & $-0.58 \pm 0.02$ & $-0.59 \pm 0.02$ & $-0.60 \pm 0.05$ & $-0.61 \pm 0.03$ \\
\hline Frozen point (\%): & $-0.60 \pm 0.05$ & $-0.59 \pm 0.02$ & $-0.61 \pm 0.03$ & $-0.62 \pm 0.03$ & $-0.61 \pm 0.03$ & $-0.64 \pm 0.03$ \\
\hline G1 & $-0.61 \pm 0.04$ & $-0.64 \pm 0.03$ & $-0.61 \pm 0.02$ & $-0.60 \pm 0.02$ & $-0.62 \pm 0.03$ & $-0.61 \pm 0.02$ \\
\hline G2 & $-0.52 \pm 0.07$ & $-0.49 \pm 0.13$ & $-0.63 \pm 0.02$ & $-0.57 \pm 0.02$ & $-0.59 \pm 0.02$ & $-0.61 \pm 0.02$ \\
\hline G3
\end{tabular}


Some rheological properties of milk:

Data in Table (6) showed that RCT values were the lowest through 6 lactation weeks in milk of ewes fed Acacia diet (G2, 98-125 seconds), and the highest in those fed Cassava diet (G4, 143-154 seconds). Such trend was associated with the lowest TS and protein content. At the end of experiment, RCT values were 143, 115, 113 and 98 seconds for Cassava, control, Atriplex and Acacia diets, respectively. RCT of milk gradually decreased till the end of lactation (Jandal, 1996).

It is clear from Table (6) that Acacia milk samples had the highest curd tension (CT) value $(65.7 \mathrm{~g})$, while the lowest was for cassava milk sample $(58.4 \mathrm{~g})$ at week 2 . The same trend of CT was observed at week 7, being 70.1, 79.2, 75.4 and $68.2 \mathrm{~g}$ for control, Acacia, Atriplex and Cassava milk, respectively. The trend of whey syneresis values of all treatments was opposite to that of curd tension. The highest values with recorded with cassava treatment compared with control and other treatments. This may be due to low TS, Protein and $\mathrm{Ca}$ in this treatment.

It is clear that higher TS content gave higher curd tension, while lower values lead to lower CT value.
Contrary to CT, syneresis was higher for lower TS and lower CT values. El- Zoghby (1994) compared buffalo, cow and goat milk admixtures, show that curd tension/ Syneresis are $(56.815 \mathrm{~g} / 14.5 \mathrm{ml}),(27.25 \mathrm{~g} / 32.5 \mathrm{ml})$ and (30.32 g/28.5 ml), respectively. Also Dimov and Mineva (1963) reported that differences between Curd Tension and Whey Syneresis may be due to increase protein of milk as affected by acidity of milk curd.

\section{Blood parameters:}

\section{Hematological parameters:}

Data in Table (7) showed that hematological parameters including count of RBCs and WBCs, hemoglobin $(\mathrm{Hg}, \mathrm{g} / \mathrm{dl})$ and heamatocrite $(\mathrm{Ht}, \%)$ concentration. Count of RBCs did not differ significantly in treatment groups (G2, G3 and G4) from that in the control group (G1). However, count of WBCs, $\mathrm{Hg}$ concentration and $\mathrm{Ht}$ were significantly $(\mathrm{P}<0.05)$ higher in $\mathrm{G} 4$ than in $\mathrm{G} 2$ and $\mathrm{G} 3$. Such findings indicated that feeding ewes on Cassava (G4) diet significantly $\quad(\mathrm{P}<0.05) \quad$ improved hematological parameters of ewes as compared to Acacia (G2) and Atriplex (G3) diets, but all did not differ from that of $\mathrm{BH}(\mathrm{G} 1)$ diet.

Table (6): Rheological properties of ewes milk in the experimental groups during different weeks of the suckling period.

\begin{tabular}{|c|c|c|c|c|c|c|c|}
\hline \multirow{2}{*}{$\begin{array}{l}\text { Suckling } \\
\text { week }\end{array}$} & \multirow{2}{*}{$\begin{array}{c}\text { Exp. } \\
\text { group }\end{array}$} & \multirow{2}{*}{$\begin{array}{c}\text { RCT/ } \\
\text { sec }\end{array}$} & \multirow{2}{*}{ CT/g } & \multicolumn{4}{|c|}{ Whey syneresis $\mathrm{ml} / \mathbf{1 0 0} \mathrm{ml}$} \\
\hline & & & & $30 \mathrm{~min}$ & $60 \mathrm{~min}$ & $90 \mathrm{~min}$ & Total \\
\hline \multirow{4}{*}{2} & G1 & 140 & 62.8 & 14.0 & 12.0 & 8.0 & 34.0 \\
\hline & G2 & 125 & 65.7 & 13.0 & 10.0 & 6.0 & 29.0 \\
\hline & G3 & 128 & 64.3 & 13.3 & 10.2 & 7.0 & 30.5 \\
\hline & G4 & 154 & 58.4 & 15.0 & 14.2 & 9.0 & 38.2 \\
\hline \multirow{4}{*}{3} & G1 & 139 & 63.7 & 13.8 & 11.8 & 7.8 & 33.4 \\
\hline & G2 & 115 & 69.5 & 12.8 & 9.8 & 5.9 & 28.5 \\
\hline & G3 & 116 & 66.1 & 13.1 & 9.9 & 7.3 & 30.3 \\
\hline & G4 & 152 & 63.1 & 14.2 & 12.5 & 8.0 & 34.7 \\
\hline \multirow{4}{*}{4} & G1 & 140 & 65.6 & 13.5 & 11.5 & 7.6 & 32.6 \\
\hline & G2 & 136 & 74.2 & 12.3 & 9.4 & 5.8 & 27.5 \\
\hline & G3 & 130 & 68.9 & 12.8 & 8.5 & 7.5 & 28.8 \\
\hline & G4 & 150 & 64.9 & 13.9 & 12 & 7.9 & 33.8 \\
\hline \multirow{4}{*}{5} & G1 & 130 & 68.1 & 13.0 & 11.1 & 7.1 & 31.2 \\
\hline & G2 & 110 & 76.3 & 12.0 & 8.8 & 5.6 & 26.4 \\
\hline & G3 & 120 & 71.2 & 12.4 & 9.0 & 6.9 & 28.3 \\
\hline & G4 & 149 & 66.7 & 13.5 & 11.5 & 7.7 & 32.7 \\
\hline \multirow{4}{*}{6} & G1 & 117 & 69.4 & 12.4 & 10.6 & 6.4 & 29.4 \\
\hline & G2 & 102 & 78.1 & 11.8 & 8.4 & 5.3 & 25.5 \\
\hline & G3 & 112 & 73.1 & 12.1 & 8.6 & 6.3 & 27.0 \\
\hline & G4 & 145 & 67.8 & 13.1 & 11.3 & 7.6 & 32.0 \\
\hline \multirow{4}{*}{7} & G1 & 115 & 70.1 & 12.0 & 10 & 6.3 & 28.3 \\
\hline & G2 & 98 & 79.2 & 11.6 & 8.0 & 5.2 & 24.8 \\
\hline & G3 & 113 & 75.4 & 11.8 & 8.5 & 6.0 & 26.3 \\
\hline & G4 & 143 & 68.2 & 12.8 & 11 & 7.5 & 31.3 \\
\hline
\end{tabular}

Table (7): Some hematological parameters (Mean \pm S.E.) of ewes in the experi-mental groups during suckling period.

\begin{tabular}{|c|c|c|c|c|}
\hline \multirow{2}{*}{ Parameter } & \multicolumn{4}{|c|}{ Experimental groups } \\
\hline & G1 & G2 & G3 & G4 \\
\hline RBCs $\left(\times 10^{6} / \mathrm{mm}^{3}\right)$ & $4.922 \pm 0.137$ & $4.314 \pm 0.434$ & $4.800 \pm 0.0764$ & $5.046 \pm 0.107$ \\
\hline $\mathrm{WBCs}\left(\mathrm{x} 10^{3} / \mathrm{mm}^{3}\right)$ & $10.13 \pm 0.28^{\mathrm{ab}}$ & $9.72 \pm 0.15^{b}$ & $9.88 \pm 0.16^{\mathrm{b}}$ & $10.38 \pm 0.22^{\mathrm{a}}$ \\
\hline $\mathrm{Hg}(\mathrm{g} / \mathrm{dl})$ & $9.58 \pm 0.27^{\mathrm{ab}}$ & $9.19 \pm 0.15^{\mathrm{b}}$ & $9.35 \pm 0.15^{b}$ & $9.83 \pm 0.21^{\mathrm{a}}$ \\
\hline $\mathrm{Ht},(\%)$ & $31.65 \pm 0.88^{\mathrm{ab}}$ & $30.37 \pm 0.47^{b}$ & $30.87 \pm 0.49^{b}$ & $32.45 \pm 0.69^{\mathrm{a}}$ \\
\hline
\end{tabular}

a and $\mathrm{b}$ : Means denoted within the same row with different superscripts are significantly $(P<0.05)$ different at $P<0.05$.

Biochemical and mineral concentration in ewe blood:

Data in Table (8) showed significant $(\mathrm{P}<0.05)$ increase in concentration of total proteins (TP), urea-N,
$\mathrm{Ca}$ and $\mathrm{Ca} / \mathrm{p}$ ratio in $\mathrm{G} 2$ in blood plasma as compared to G4, while both groups did not differ significantly from those in other groups (G1 and G3). However, concentration of creatinine, triglycerides and total 


\section{EL-Saadany, S.A. et al.}

cholesterol significantly $(\mathrm{P}<0.05)$ increased in $\mathrm{G} 2$ and glucose concentration significantly $(\mathrm{P}<0.05)$ increased in G3 as compared to G1 (control). On the other hand, the effect of dietary treatment on concentration of albumin (AL), globulin (GL), AL/GL ratio and $\mathrm{P}$ in blood plasma of ewes was not significant.

Table (8): Some biochemical parameters(Mean \pm S.E.) in blood plasma of ewes in the experimental groups during suckling period.

\begin{tabular}{|c|c|c|c|c|}
\hline \multirow[b]{2}{*}{ Item } & \multicolumn{4}{|c|}{ Experimental groups } \\
\hline & G1 & G2 & G3 & G4 \\
\hline Total proteins, g/dl & $7.60 \pm 0.25^{\mathrm{ab}}$ & $7.89 \pm 0.10^{\mathrm{a}}$ & $7.48 \pm 0.32^{\mathrm{ab}}$ & $6.95 \pm 0.19^{b}$ \\
\hline Albumin (AL), g/dl & $4.38 \pm 0.34$ & $4.84 \pm 0.16$ & $4.48 \pm 0.41$ & $4.20 \pm 0.37$ \\
\hline Globulin (GL), g/dl & $3.22 \pm 0.15$ & $3.05 \pm 0.11$ & $3.00 \pm 0.26$ & $2.75 \pm 0.27$ \\
\hline AL/GL ratio & $1.50 \pm 0.16$ & $1.63 \pm 0.11$ & $1.82 \pm 0.48$ & $1.85 \pm 0.39$ \\
\hline Urea-N, mg/dl & $67.36 \pm 2.23^{\mathrm{ab}}$ & $69.91 \pm 0.87^{\mathrm{a}}$ & $66.21 \pm 2.84^{\mathrm{ab}}$ & $61.62 \pm 1.71^{\mathrm{b}}$ \\
\hline Creatinine, $\mathrm{mg} / \mathrm{dl}$ & $0.68 \pm 0.02 \mathrm{~A}^{\mathrm{b}}$ & $0.71 \pm 0.4^{\mathrm{a}}$ & $0.68 \pm 0.03^{\mathrm{ab}}$ & $0.63 \pm 0.02^{\mathrm{b}}$ \\
\hline Glucose, $\mathrm{mg} / \mathrm{dl}$ & $66.85 \pm 4.71^{\mathrm{b}}$ & $60.28 \pm 0.29^{b}$ & $87.00 \pm 2.15^{\mathrm{a}}$ & $62.71 \pm 3.61^{\mathrm{b}}$ \\
\hline Triglycerides, mg/dl & $47.46 \pm 3.80^{\mathrm{b}}$ & $69.62 \pm 1.75^{\mathrm{a}}$ & $62.32 \pm 2.71^{\mathrm{a}}$ & $50.95 \pm 2.33^{\mathrm{b}}$ \\
\hline Total cholesterol, mg/dl & $86.11 \pm 1.99^{b}$ & $93.55 \pm 1.46^{\mathrm{a}}$ & $82.84 \pm 2.31^{\mathrm{b}}$ & $71.34 \pm 1.62^{\mathrm{c}}$ \\
\hline $\mathrm{Ca}, \mathrm{mg} / \mathrm{dl}$ & $10.45 \pm 0.35^{\mathrm{ab}}$ & $10.84 \pm 0.13^{\mathrm{a}}$ & $10.28 \pm 0.44^{\mathrm{ab}}$ & $9.56 \pm 0.27^{b}$ \\
\hline $\mathrm{P}, \mathrm{mg} / \mathrm{dl}$ & $3.41 \pm 0.27$ & $3.09 \pm 0.18$ & $3.01 \pm 0.34$ & $3.64 \pm 0.11$ \\
\hline $\mathrm{Ca} / \mathrm{p}$ ratio & $3.26 \pm 0.30^{\mathrm{ab}}$ & $3.62 \pm 0.22^{\mathrm{a}}$ & $3.75 \pm 0.14^{\mathrm{a}}$ & $2.66 \pm 0.13^{b}$ \\
\hline
\end{tabular}

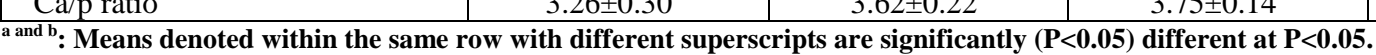

The observed significant $(\mathrm{P}<0.05)$ reduction in TP concentration in G4 than in G2 may be associated with incidence of more pregnancies in G4 than in G2. In this respect, Sikka (2004) reported that the decrease of total protein during pregnancy leads to decrease in protein synthesis in the liver. Al-Zamely (2011) found significant decrease $(\mathrm{P}<0.05)$ in $\mathrm{TP}$ concentration in pregnant in comparison with non-pregnant. Generally, the present values of TP, AL, GL and AL/GL ratio are within the normal range reported by (Hassan et. al., and Fasae et. al., 2015).

\section{Growth performance of offspring:}

Data presented in Table (9) show significant $(\mathrm{P}<0.05)$ differences in average LBW of lambs produced from different experimental groups at birth. Average LBW of lambs at birth was significantly $(\mathrm{P}<0.05)$ higher in treatment groups (G2, G3 and G4) than in G1 (control). The same trend was observed in LBW of males rather than that of females. It is worthy noting that LBW, total gain and average daily gain of lambs (males and females) was not affected at different ages. These results agreement with Shetaewi et. al.,2001 and Fasae et. al., 2015).

Table (9): Average (Mean \pm S.E.) live body weight (males and females) of lambs at different ages produced from ewes in the experimental groups.

\begin{tabular}{|c|c|c|c|c|}
\hline \multirow{2}{*}{ Lamb age (wk) } & \multicolumn{4}{|c|}{ Experimental groups } \\
\hline & G1 & G2 & G3 & G4 \\
\hline \multicolumn{5}{|c|}{ Average live body weight $(\mathrm{kg})$ : } \\
\hline At birth & $3.69 \pm 0.10^{\mathrm{b}}$ & $3.79 \pm 0.17^{\mathrm{a}}$ & $3.83 \pm 0.13^{\mathrm{a}}$ & $3.89 \pm 0.20^{\mathrm{a}}$ \\
\hline $2 \mathrm{wk}$ & $7.05 \pm 0.15$ & $6.87 \pm 0.31$ & $6.96 \pm 0.50$ & $6.25 \pm 0.43$ \\
\hline $4 \mathrm{wk}$ & $10.26 \pm 0.23$ & $9.95 \pm 0.63$ & $9.96 \pm 0.94$ & $10.24 \pm 0.79$ \\
\hline $6 \mathrm{wk}$ & $11.34 \pm 0.19$ & $10.66 \pm 0.54$ & $10.93 \pm 0.95$ & $11.36 \pm 0.82$ \\
\hline $8 \mathrm{wk}$ & $12.13 \pm 0.19$ & $11.59 \pm 0.50$ & $12.61 \pm 0.95$ & $13.08 \pm 0.85$ \\
\hline Total gain $(\mathrm{kg} / \mathrm{h})$ & $8.43 \pm 0.12$ & $8.30 \pm 0.59$ & $8.78 \pm 0.90$ & $9.81 \pm 0.82$ \\
\hline Total daily gain $(\mathrm{kg} / \mathrm{h} / \mathrm{d})$ & $0.150 \pm 0.00$ & $0.140 \pm 0.10$ & $0.156 \pm 0.02$ & $0.164 \pm 0.01$ \\
\hline \multicolumn{5}{|l|}{ Male weight $(\mathrm{kg} / \mathrm{h})$ : } \\
\hline At birth & $3.75 \pm 0.19^{b}$ & $4.14 \pm 0.14^{\mathrm{a}}$ & $4.16 \pm 0.04^{\mathrm{a}}$ & $4.25 \pm 0.09^{\mathrm{a}}$ \\
\hline 2 wk of age & $7.15 \pm 0.24$ & $7.13 \pm 0.27$ & $7.30 \pm 0.62$ & $7.81 \pm 0.24$ \\
\hline 4 wk of age & $10.26 \pm 0.30$ & $10.12 \pm 0.56$ & $10.18 \pm 1.20$ & $11.04 \pm 0.56$ \\
\hline 6 wk of age & $11.51 \pm 0.51$ & $10.86 \pm 0.52$ & $11.40 \pm 1.29$ & $12.64 \pm 0.38$ \\
\hline 8 wk of age & $12.33 \pm 0.57$ & $12.59 \pm 0.51$ & $13.41 \pm 1.37$ & $14.16 \pm 0.75$ \\
\hline Total gain $(\mathrm{kg} / \mathrm{h})$ & $8.58 \pm 0.12$ & $8.45 \pm 0.37$ & $9.25 \pm 1.35$ & $9.91 \pm 0.45$ \\
\hline Daily gain $(\mathrm{g} / \mathrm{h} / \mathrm{d})$ & $0.153 \pm 0.00$ & $0.150 \pm 0.02$ & $0.165 \pm 0.02$ & $0.177 \pm 0.01$ \\
\hline \multicolumn{5}{|l|}{ Female weight $(\mathrm{kg} / \mathrm{h})$ : } \\
\hline At birth & $3.64 \pm 0.11$ & $3.44 \pm 0.23$ & $3.50 \pm 0.16$ & $3.54 \pm 0.33$ \\
\hline 2 wk of age & $6.96 \pm 0.21$ & $6.61 \pm 3.04$ & $6.63 \pm 0.93$ & $6.49 \pm 0.76$ \\
\hline 4 wk of age & $10.26 \pm 0.34$ & $9.78 \pm 1.21$ & $9.75 \pm 1.74$ & $9.44 \pm 1.45$ \\
\hline 6 wk of age & $11.16 \pm 0.27$ & $10.46 \pm 0.52$ & $10.53 \pm 1.67$ & $10.08 \pm 1.49$ \\
\hline 8 wk of age & $11.93 \pm 0.27$ & $11.59 \pm 0.51$ & $11.81 \pm 1.64$ & $12.00 \pm 1.53$ \\
\hline Total gain $(\mathrm{kg} / \mathrm{h})$ & $8.29 \pm 0.16$ & $8.15 \pm 1.27$ & $8.31 \pm 1.49$ & $8.46 \pm 1.20$ \\
\hline Daily gain $(\mathrm{g} / \mathrm{h} / \mathrm{d})$ & $0.148 \pm 0.00$ & $0.130 \pm 0.01$ & $0.148 \pm 0.02$ & $0.151 \pm 0.03$ \\
\hline
\end{tabular}

and $\mathrm{b}$ : Means denoted within the same row with different superscripts are significantly $(P<0.05)$ different at $P<0.05$. 
This means that feeding ewes pre- and postpartum period on different forage types in this study was save without adversely effects on growth performance of lambs produced. Similarly, feeding additional fats in isoenergetic diets during late pregnancy improved lamb birth weight (Ghoreishi et al., 2007).

\section{CONCLUSION}

Halophyte shrubs are distinguished with minimum use of brackish or saline irrigation water and tolerable to arid or semi-arid conditions. It also give good biomass yield which could be used for feeding sheep and goat. This experiment concluded that Atriplex , Acacia and Cassava could be used as forage for Barki ewes at level of $30 \%$ instead of berseem hay with $10 \%$ rice straw and $60 \%$ concentrate feed mixture during the late pregnancy and postpartum period. Experimental treatments did not result any adverse effects. Ewes fed on Cassava yielded the highest milk production. Atriplex, Acacia and Cassava did not result any adverse effect on live body weight of ewes or their lambs.

\section{REFERENCES}

Abdalla, E.B; H.A. Gawish; A.M. El-Sherbiny; N.H. Ibrahim and A.S. El-Hawy (2013). Reproductive Efficiency of Damascus Goats in Salt-Affected Lands in South Sinai, Egypt. Journal of American Science, 9(8): 170-177. http : // www . americanscience . org

Abd El-Salam. M. H., El-Shbiny, S. Mahfouz, M. B; ElDein H. F.; El. Atriby, H. and Antila. V. (1991). Preparation of whey protein concentrate from salted whey and its use in Yoghurt. J. Dairy Res. 58-503.

Abdel-Wahed, A.M. (2014). Effects of type of roughage and level of concentrate supplements on feed digestion and utilization in growing female dromedary camels. Journal of American Science, 10(6): 198-206.

Abou El Nasr, H. M., H. M. Kandil, A. El KerdawyH. S. Dawlat, Khamis and H. S. El-Shaer (1996). Value of processed saltbush and Acacia shrubsas sheep fodders under the arid conditions ofEgypt. Small Ruminant Res., 24: 15-20.

Abu-Zanat, M.M.W. and Tabbaa, M.J. (2006). Effect of feeding Atriplex browse to lactating ewes on milk yield and growth rate of their lambs. J. Small Rum. Res .pp: 152-161.

Afaf, M. Fayed, Abeer, M. El-Essawy, E.Y. Eid, H.G. Helal, Ahlam, R. Abdou and H.M. El Shaer (2010). Utilization of Alfalfa and Atriplex for Feeding Sheep under Saline Conditions of South Sinai, Egypt. Journal of American Science, 6(12).

Al-Dobaib, S.N., M.A. Mehaia and M.H. Khalil (2009). Effect of feeding discarded dates on milk yield and composition of Aradi goats. Small Ruminant Research, 81(2-3):167-170.
Al-Saiady, M.Y., H.H. Mogawer, B. Faye, S.E. AlMutairi, M. Bengoumi, A. Musaad and A. GarElnaby (2012). Some factors affecting dairy shecamel performance Emir. J. Food Agric., 24 (1): 85-91.

Al-Zamely, H.A.N. (2011). Oxidant-antioxidant status and some biochemical parameters in pregnant and non pregnant Iraqi she-camels. The Iraqi J. Vet. Med., 35 (2): 46-51.

A.O.A.C. (1984). Association of Official Analytical Chemists, Official Methods of Analysis.

A.O.A.C. (1995). Official Methods of Analysis (16th) Edt. Association of Official Analytical Chemists; Washington; D.C.; USA.

Barnett, A,S, and Abdel-Tawab, G. (1957). A rapid method for determination of lactose in milk and cheese, J, sci. Food Agric.,8;437.

Bayoumi, M.T.; H. M. El-shaer and Fawzia Asaad (1990). Survival of sheep and goats fed salt march plants. J. Arid Environments, 18: 75-78.

Berrige, N. J. (1952). Some observations on the determination of the activity of Rennet . Analyst, 77: 57.

Chandrosekhara, M.R.; Swaminan, M. and Subrahmanyan, V. (1975). The use of mammalian milk food processed with foods in feeding of infants. Indian J. Chid Health. (1975) D. 701 .

Davison, T.M., F.P. Vervoort and F. Duncalfe (1991). Responses to a long-chain fatty acid supplement fed to dairy cows at two stages of lactation. Aust. J. Exp. Agric., 31: 467-470.

Degan, A.A., Becker, K., Makkar, H.P.S., Borowy, N. (1995). Acacia saligna asfodder tree for desert livestock and the interaction of its tannins with fiberfractions., J. Sci. Food Agric., 68: $65-71$.

Degan, A.A., Blankc, A., Beker, K., Kam, M., Benjamin, R.W., Makkar, H.P.S ,.(1997).The nutritive value of Acacia saligna and Acacia saligna for goatsand sheep. J. Anim. Sci., 64: 253-259.

Dimov, N. and Mineva, P., 1963. Effect of some factors on the syneresis of fresh cured and losses of solids in the Whey in the processing of cow's , ewes' and buffalos milk. Daily Sci. Abst., 255.

Duncan, D. B. (1955). Multiple Range's and Multiple Ftest. Biometrics, 11: 1-42.Version 8.0 Edition. SAS Inst., Inc., Cary, NC.

El- Zoghby, A. S. (1994). Studies on Mozzarella Cheese Ph. D. Thesis Food Science Dept., Faculty of Agriculture Zagazig University.

Fasae, O. A.; Amos, A. O.; Owodunni, A.; Yusuf, A. O.(2015). Performance,

haematological parameters and faecal egg count of semi-intensively managed West African dwarf sheep to varying levels of cassava leaves and peels supplementation. Pertanika J, of Tropical Agric. Sci.;. 38(1):71-81. 
Ghoreishi, S.M., M.J. Zamiri and E. Rowghani (2007). Effect of a calcium soap of fatty acids on reproductive characteristics and lactation performance of fat-tailed sheep. Pakistan Journal of Biological Sciences, 10: 2389-2395.

Gihad, E. A. and H. M. El-Shaer (1994).Halophytes as animal feed in Egyptian deserts In: V. Squires and A. Ayoup (eds): Halophytes as a source for livestock and rehabilitation of degraded for lands. Kluwer A. C, pub, T; Vs 32, pp. 77-96.

Hassan, A.A., (2009) Effect of some enrichment and biological treatments on amelioration Utilization of Atriplex nummularia feed by sheep. Egyptian K. Nutrition and feeds, 12 (3) Special.

Hassan, A. A.; Salma, H. Abou Hafsa; M.H. Yacout; M.S. Khalel; M.A.R. Ibrahim; Dorina Mocuta (2015). Effect of feeding some forage shrubs on Goats performance and rumen fermentation ulin dry season.Egyptian Journal of Sheep and Goats Sciences, Proceedings Book of the $5^{\text {th }}$ Intrnational Scientific Conference on Small Ruminant Production, Sharm El Sheikh-Egypt, $\mathrm{p}: 21-36$.

Jandal J. M. ( 1996 ) . Comparative aspects of goat and sheep milk. Small Rumin. Res., 22, 177 - 185.

John, M.K. (1970). Colorimetric determination of phosphorous in soil and plant materials with ascorbic acid. Soil Sci., J.109(4) 214-220.

Khaskheli, M., M.A. Arain, S. Chaudhry, A.H. Soomro and T.A. Qureshi (2005). Physico-chemical quality of camel milk. J of Agric. and Social Sciences, 2:164-66.

Lawerence, A. J. (1959). Syneresis of rennet curd Aust. J. Dairy Technology 14: 166.

Le Houerou, H.N., (1992). The role of saltbushes (Atriplex spp.) in arid land rehabilitation in the Mediterranean Basin: A review, Agro forestry systems, $18: 108-148$.

Ling (1963). A Text Book Of Dairy Chemistry. ${ }^{\text {rd }}$ ed., Vol. 2 Chapman and Hall London UK.

Mona I. Mohammady, A.H. Hammam and N. H. Ibrahim, (2014). Returns and Economical Efficiency of Barki Sheep Fedon Salt Tolerant Plants in Sinai, Egypt. Journal of American Science; 10 (4):134-139.

Mervat Mohammed Al-Bayumi , M., I.(2008). Nutritonal and Immunological studies on Barki sheep milk Ph. D. Thesis Fac. Agr., Alex. Univ., Damanhour.

N. R. C. (1985). Nutrient Requirements of Sheep. Sixth Revised Edition, National research council, National academy press, Washington, D.C.

Ochoa -cordero, M. A., Hernandez, G. T. and OchoaAlforo, A. E. (2002). Milk yield and composition of Rambouillet ewes under intensive management. Small Ruminant Research, 43: 269.

Page, A. I.,(1982). Methods of soil analysis, II Chemical and Microbiological properties.(Ed.2) Sci. Am. Inc., Madison, W.I.
Park, Y. W. (2006). Goat milk-chemistry and nutrition. In park Y. W. Haenlein, G.F W (Eds) Hand book of milk on Non bovine Mammals Blackwell Publishing professional Oxford, U K/Ames, Iowo, pp 34-58.

Park, Y. W., Juarez, M.; ramos, M. and Haenlein, G. F. W. (2007).Physico-chemical characteristics of goat and sheep milk, Small Res., 68: 88.

Phanthavong Vongsamphanh and Metha Wanapat (2004). Comparison of cassava hay yield and chemical composition of local and introduced varities and effects of levels of cassava hay supplementation in native beef cattle fed on rice straw, Livestock Research for Rural Development 16(8).

Renner, E . 1982. Milch und Milchprodukte in der Ernaehrung des Menschen. Volkswirtschaftlicher Verlag, Munich, Germany, 467 p.

Riaz, M., S.H. Hanjra, R.A. Gill and A.A. Gill (1994). Growth and carcass characteristics of Teddy goats affected by atriplex feeding. Pakistan J. Agri. Sci., 31: 318-321.

Rincon, F.; Moreno, R; Zurera, G. and Amaro, M. (1994). Mineral composition as a characteristic for the identification of animal origin of raw milk J. Dairy Res., 61 (5).

Safinaz M. Shawket M.H. Ahmed and M. A. Ibrahim (2010). Impact of feeding Atriplex halimus and Acacia Saligna with different sources of energy on lambs performance. Eg. J. of Sh and G. Sci., Vol. 5 (1), P: 191-208.

SAS (1999). Statistical Analysis Systems Institute. SAS User's Guide. Statistics.

Shaker, Y.M.; N.H. Ibrahim; F.E. Younis; and H.M. El Shaer (2014). Effect of Feeding Some Salt Tolerant Fodder Shrubs Mixture on Physiological Performance of Shami Goats in Southern Sinai, Egypt. Journal of American Science;10 (2s), pp 66-76.

Shetaewi, M. M. 1; Abdel-Samee, A. M. 1; Bakr, E. A. 1 (2001). Reproductive Performance and Milk Production of Damascus Goats Fed Acacia Shrubs or Berseem Clover Hay in North Sinai, Egypt. Tropical Animal Health \& Production. 33(1):67-79.

Sikka, S.C. (2004). Role of oxidative stress and antioxidants in andrology and assisted reproductive technology. J. Andro., 25: 5-18.

Shiroma, S. and Akashi, A. (1976). Degradation of mimosine in Leucaena leucocephala de Wit by goal rumen microorganisms. Nippon Chikusan Gakkai-ho; 47: 739- 747.

Srivastavam, S. N. L. and Sharma, K. (1998). Response of goats to pelleted diets containing different proportions of sun-dried Leucaena leucocephala. Small Ruminant Research 28139-148.

Wilson, R.T. (1984). The Camel. Longman, London Kamoun, M.P. Girard, and R. Bergaoui. 1989. Alimentation et croissance du dromadaire. Effect d'un aliment concentre sur l'ingestion de matiere et la croissance du chameleon en Tunisie. Rev Elev. Med. Vet. Pays Trop., 42: 89-94. 


\section{J.Animal and Poultry Prod., Mansoura Univ., Vol. 7 (1), January, 2016}

Wilson, A.D., (1992). Halophytic plants communities in Australia: Ecology and potential as a rangeland resource. Proc. Inter. Workshop, Halophytes as aresource for livestock and for rehabilitation of degraded land.
Zarkawi, M.; M.R. Al-Masri; and K. Khalifa (2005). Nutritive value of Sesbania aculeate grown on salty soil and its effect on reproductive parameters of Syrian Awassi ewes .Aust. J. of Anim. Res., 56 (8): pp. 819-825.

\section{تأثثير تغذية بعض الثجيرات العلفية على اللبن ، مقاييس الام للنعاج وأداء نمو حملانها في الساحل الشمالي.

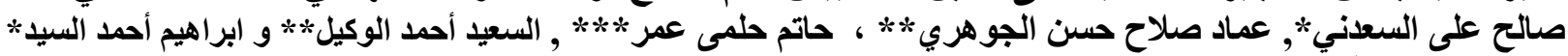

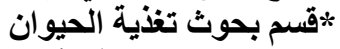

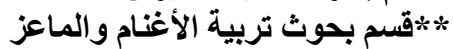 ****قم بحوث تكنولوجيا الالبان ، معهد بحوث الإنتاج الحيواني، مركز البحوث الزراعية، وزارة الزراعة، مصر}

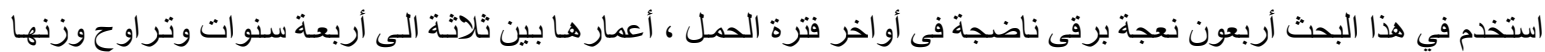

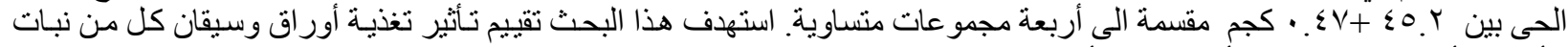

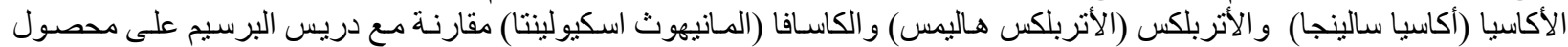

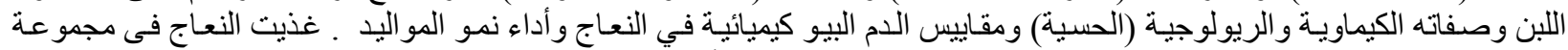

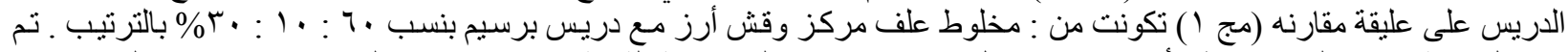

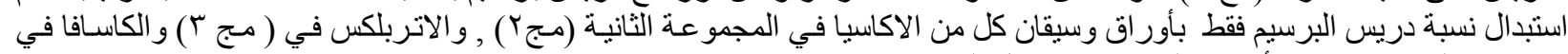

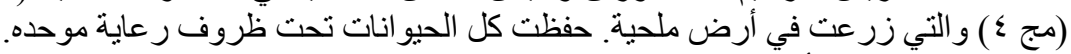

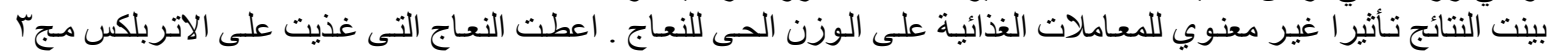

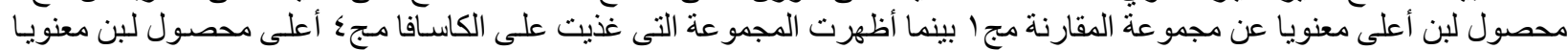

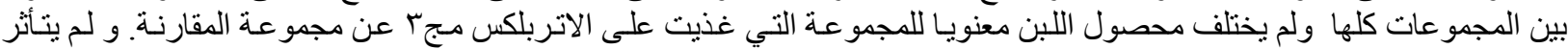

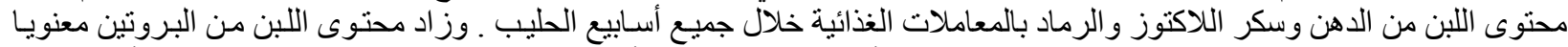

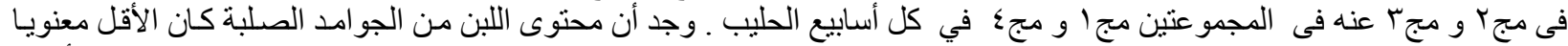

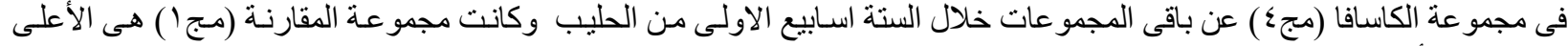

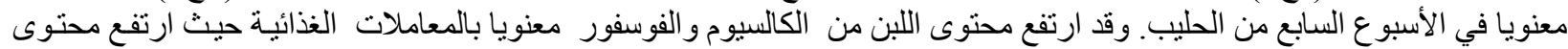

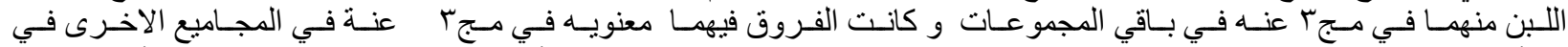

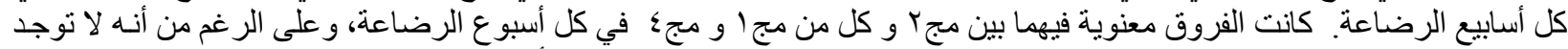

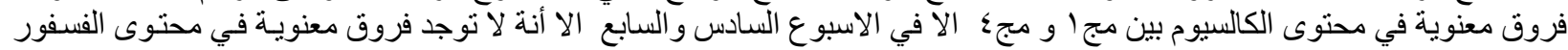

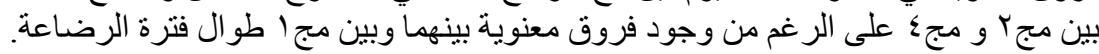

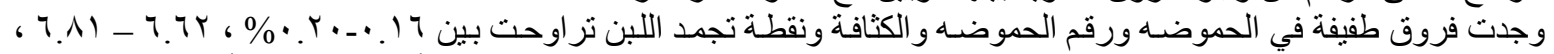

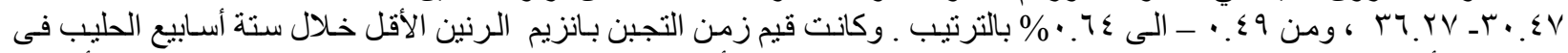

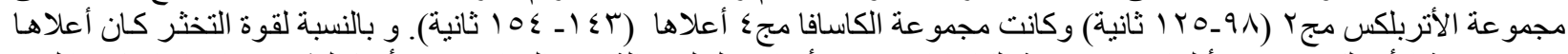

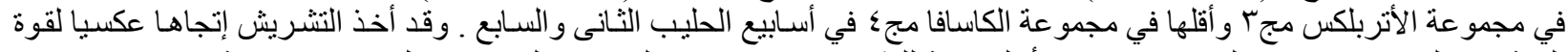

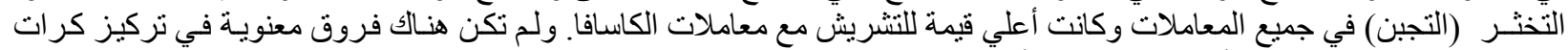

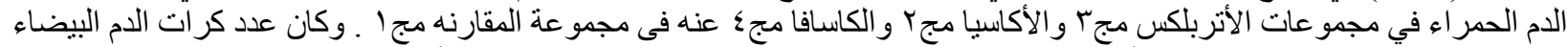

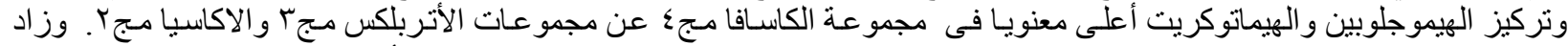

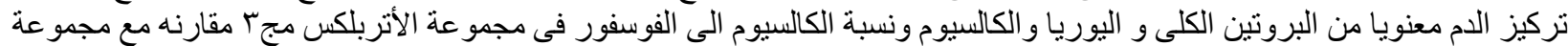

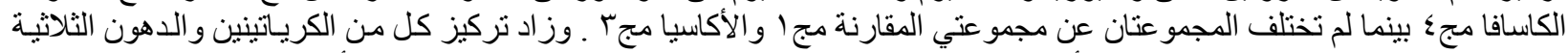

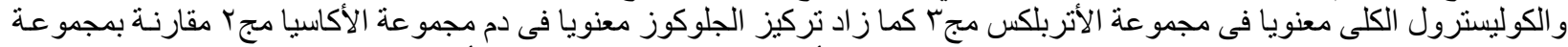

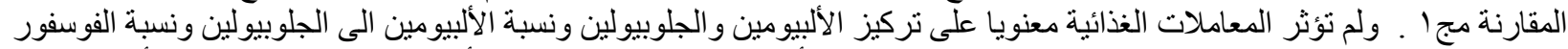

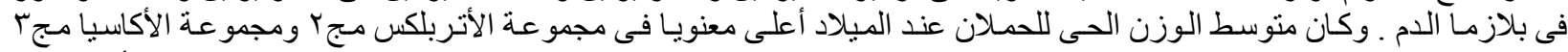

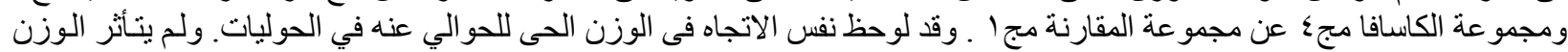

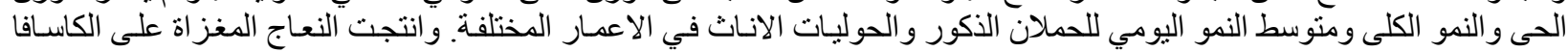

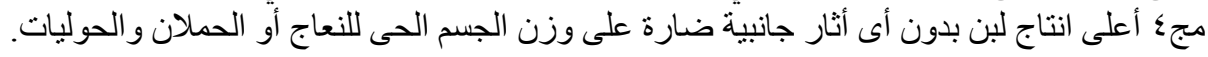

